\title{
Effect of Fertigation Levels and Different Spacings on Yield and Yield Attributes of Bell Pepper (Capsicum annuum L.var.grossum sendt.) in Polyhouse condition
}

\author{
Athira R. $\mathrm{C}^{1}$ and T. Sajitha Rani ${ }^{2}$
}

${ }^{1}$ MSc Scholar, Department of Agronomy, College of Agriculture, Vellayani, Thiruvananthapuram, Kerala Agricultural University, Kerala, India.

${ }^{2}$ Professor, Department of Agronomy, College of Agriculture, Vellayani, Thiruvananthapuram, Kerala Agricultural University, Kerala, India.

\begin{abstract}
An experiment was carried out in bell pepper (Capsicum annuum L.var.grossum sendt.) to study the influence of fertigation levels and different spacings on yield and yield attributes under polyhouse condition.The perusal of the data revealed that widely spaced $(45 \mathrm{~cm} \times 60 \mathrm{~cm})$ plants produced the highest number of fruits plant ${ }^{-1}(13.75)$, fruit girth $(25.23 \mathrm{~cm})$ and fruit yield plant ${ }^{-1}(1.53 \mathrm{~kg})$ while fruit yield $\mathrm{m}^{-2}$ $(8.92 \mathrm{~kg})$ was the highest for closely spaced $(45 \mathrm{~cm} \times 30 \mathrm{~cm})$ plants. Yield and yield attributes were significantly influenced by fertigation levels. Among the fertigation levels, $100 \%$ adhoc recommendation of KAU for precision farming (230: 25: $250 \mathrm{~N}, \mathrm{P}_{2} \mathrm{O}_{5}$ and $\mathrm{K}_{2} \mathrm{O} \mathrm{kg} \mathrm{ha} \mathrm{kg}^{-1}$ ) registered the highest number of fruits plant $^{-1}(15.15)$, fruit girth $(26.24 \mathrm{~cm})$, fruit yield plant ${ }^{-1}(1.72 \mathrm{~kg})$ and fruit yield $\mathrm{m}^{-2}(8.30 \mathrm{~kg})$.
\end{abstract}

Keywords-bellpepper, fertigation, spacing, foliar nutrition, yield and yield attributes.

\section{INTRODUCTION}

Bell pepper (Capsicum annuum L.var.grossum sendt.) also known as capsicum, sweet pepper or shimla mirch is one among the most popular vegetables grown in polyhouses worldwide. The bell pepper fruits are available in different attractive colours and they have great demand in markets. Bell pepper is rich in proteins, vitamin A, ascorbic acid, riboflavin, thiamin, niacin and minerals like potassium, magnesium and calcium (Joshi and Singh, 1975). Being a cool season crop, year round production of quality bell pepper fruits is not possible in open field condition. Crops are more vulnerable to weather fluctuations in open field (Ochigbu and Harris, 1989) with more pests and diseases incidence leading to low productivity as well as quality. Protected cultivation techniques can be effectively utilized for the production of good quality produce with high productivity. Compared to open field cultivation, polyhouse cultivation resulted in 2-3 times yield enhancement in bell pepper (IIHR, 2011). Efficient and optimum application of fertilizer under protected condition ensures improved growth, yield and quality of bell pepper along with minimized loss of inputs and increased economic benefits. Adoption of appropriate plant spacing is one of the important aspects of successful crop production. Optimum plant spacing ensures proper growth and development of plants resulting in maximum yield of crop and economic use of land.

\section{MATERIALS AND METHODS}

A field trial was done to study the influence of fertigation levels and different spacings on yield and yield attributes of bell pepper under polyhouse condition. The soil of experiment plot was sandy clay loam, acidic in reaction, high in organic carbon and available phosphorus, low in available nitrogen and potassium. The study was laid out in split plot design with 12 treatment combinations replicated three times. The main plot treatments consisted of four levels of fertigation viz., $100 \%$ adhoc recommendation of KAU for precision farming $\left(\mathrm{F}_{1}\right), 50 \%$ adhoc recommendation of KAU for precision farming $\left(\mathrm{F}_{2}\right)$, $50 \%$ adhoc recommendation of KAU for precision farming + foliar spray of combined solution of urea and potassium chloride each at $1.25 \%$ at 30 and 60 DAT $\left(\mathrm{F}_{3}\right)$ and $25 \%$ adhoc recommendation of KAU for precision 
farming + foliar spray of combined solution of urea and potassium chloride each at $1.25 \%$ at 30 and 60 DAT $\left(\mathrm{F}_{4}\right)$. Farmyard manure@ $25 \mathrm{t} \mathrm{ha}^{-1}$ was given as basal to all the treatments. The KAU adhoc recommendation of bell pepper for precision farming is 230:25:250 N, $\mathrm{P}_{2} \mathrm{O}_{5}$ and $\mathrm{K}_{2} \mathrm{O} \mathrm{kg} \mathrm{ha}{ }^{-1}$ as fertigation along with $24 \mathrm{~kg} \mathrm{ha}^{-1}$ rajphos as basal. The details of nutrients used for fertigation as per KAU adhoc recommendation of bell pepper for precision farming are given in Table 1. For treatments requiring foliar nutrition combined solution of urea and potassium chloride each at $1.25 \%$ was given. The subplot treatments consisted of three spacings viz., $45 \mathrm{~cm} \mathrm{x} 30 \mathrm{~cm}(\mathrm{~S} 1), 45 \mathrm{~cm}$ x $45 \mathrm{~cm}(\mathrm{~S} 2)$ and $45 \mathrm{~cm} \mathrm{x} 60 \mathrm{~cm}(\mathrm{~S} 3)$.

Table 1. Fertigation schedule as per KAU adhoc recommendation of bell pepper for precision farming

\begin{tabular}{|c|c|c|}
\hline $\begin{array}{c}\text { Time of } \\
\text { application }\end{array}$ & Fertilizer & Kg ha $^{-1}$ \\
\hline Basal & Rajphos & 24 \\
\hline $\begin{array}{c}\text { 3 DAP to 18 } \\
\text { DAP }\end{array}$ & $19: 19: 19$ & 3.150 \\
\hline & $13: 00: 45$ & 3.700 \\
\hline 21 DAP to 54 & $19: 00: 00$ & 10.100 \\
\hline DAP & $13: 00: 45$ & 0.000 \\
\hline & $46: 00: 00$ & 3.7400 \\
\hline DAT & $12: 61: 00$ & 0.490 \\
\hline & $19: 19: 19$ & 1.580 \\
\hline 57DAT to 120 & $13: 00: 45$ & 14.700 \\
\hline & $46: 00: 00$ & 9.500 \\
\hline & $12: 61: 00$ & 0.490 \\
\hline
\end{tabular}

\section{RESULTS AND DISCUSSION}

Among different fertigation levels $F_{1}$ (100\% adhoc recommendation of KAU for precision farming) recorded the highest number of fruits plant ${ }^{-1}$ (15.15) followed by $\mathrm{F}_{3}$ (50\% adhoc recommendation of KAU for precision farming + foliar spray at 30 and 60 DAT) (13.49) and $\mathrm{F}_{2}(50 \%$ adhoc recommendation of KAU for precision farming) (12.37). Maximum fruit girth $(26.24 \mathrm{~cm})$ was recorded from $\mathrm{F}_{1}$ and it was on par with $\mathrm{F}_{3}(25.24 \mathrm{~cm})$ and significantly superior to $F_{2}(23.89 \mathrm{~cm})$ and $F_{4}(22.25 \mathrm{~cm})$. $\mathrm{F}_{1}$ also recorded higher fruit yield plant ${ }^{-1}(1.72 \mathrm{~kg})$ and fruit yield $\mathrm{m}^{-2}(8.30 \mathrm{~kg})$. Similar findings of increased yield in bell pepper with $252 \mathrm{~kg} \mathrm{~N}$ and $240 \mathrm{~kg} \mathrm{~N}$ was reported by Hartz et al. (1993) and Aliyu (2002) respectively. The increased availability of nutrients for the treatment $F_{1}$ might have increased the photosynthate accumulation enhancing the yield attributes and yield. Similar finding of increased fruit weight, yield plant ${ }^{-1}$ and yield $\mathrm{ha}^{-1}$ with higher dose of NPK (250:200:200 $\mathrm{kg} \mathrm{ha}^{-1}$ ) was reported by Shrivastava (1996).

Yield and yield attributes were significantly influenced by different plant spacings. The treatment $\mathrm{S}_{3}$ $(45 \mathrm{~cm} \times 60 \mathrm{~cm})$ recorded the highest number of fruits plant $^{-1}(13.75)$, fruit girth $(25.23 \mathrm{~cm})$ and fruit yield plant ${ }^{-1}$ $(1.53 \mathrm{~kg})$. The number of fruits plant ${ }^{-1}$ at $45 \mathrm{~cm} \mathrm{x} 30 \mathrm{~cm}$ $\left(\mathrm{S}_{1}\right)$ and $45 \mathrm{~cm} \mathrm{x} 45 \mathrm{~cm}\left(\mathrm{~S}_{2}\right)$ were $12.58,12.67$ respectively which were on par The lowest fruit girth was reported by $\mathrm{S}_{1}(23.33 \mathrm{~cm})$ and it was on par with $\mathrm{S}_{2}(24.66 \mathrm{~cm})$. Similarly lowest fruit yield plant $^{-1}(1.30 \mathrm{~kg})$ was obtained from $S_{1}(45 \mathrm{~cm} \times 30 \mathrm{~cm})$ and it was on par with $S_{2}(45 \mathrm{~cm}$ x $60 \mathrm{~cm})(1.36 \mathrm{~kg})$. Higher yield and yield attributes for $\mathrm{S}_{3}$ might be due to higher availability of sunshine, more space and less competition for nutrients which in turn promoted more number of flowers and increased photosynthate accumulation. Similar results of higher yield and yield attributes with wider spacing in bell pepper were reported by Alam et al. (2011) and Biradar et al. (2014). Maximum total fruit yield $\mathrm{m}^{-2}$ was obtained from closely spaced plants $(45 \mathrm{~cm}$ x $30 \mathrm{~cm})(8.92 \mathrm{~kg})$ followed by $\mathrm{S}_{2}$ $(6.74 \mathrm{~kg})$ and both the treatments were significantly superior over $S_{3}$ (5.67). The higher plant population in closer spacing resulted in higher fruit yields $\mathrm{m}^{-2}$ compared to wider spacing. Similar findings of increased fruit yield $\mathrm{ha}^{-1}$ with closer spacing were reported by Zende (2008) and Shivakumar et al. (2012). 
Table 2. Effect of fertigation levels on yield and yield attributes of bell pepper under polyhouse condition.

\begin{tabular}{|l|l|l|l|l|}
\hline Treatments & Number of fruits plant ${ }^{-1}$ & Fruit girth $(\mathrm{cm})$ & $\begin{array}{l}\text { Total Fruit Yield } \\
\text { Plant }^{-1}(\mathrm{~kg})\end{array}$ & $\begin{array}{l}\text { Total Fruit Yield } \\
\mathrm{m}^{-2}(\mathrm{~kg})\end{array}$ \\
\hline $\mathrm{F}_{1}$ & 15.15 & 26.24 & 1.72 & 8.30 \\
\hline $\mathrm{F}_{2}$ & 12.37 & 23.89 & 1.32 & 6.84 \\
\hline $\mathrm{F}_{3}$ & 13.49 & 25.24 & 1.40 & 7.19 \\
\hline $\mathrm{F}_{4}$ & 11.00 & 22.25 & 1.15 & 6.10 \\
\hline $\mathrm{CD}(0.05)$ & 0.909 & 1.274 & 0.120 & 0.656 \\
\hline
\end{tabular}

Table 3. Effect of different spacings on yield and yield attributes of bell pepper under polyhouse condition.

\begin{tabular}{|l|l|l|l|l|}
\hline Treatments & Number of fruits plant ${ }^{-1}$ & Fruit girth $(\mathrm{cm})$ & $\begin{array}{l}\text { Total Fruit Yield } \\
\text { Plant }^{-1}(\mathrm{~kg})\end{array}$ & $\begin{array}{l}\text { Total Fruit Yield } \\
\mathrm{m}^{-2}(\mathrm{~kg})\end{array}$ \\
\hline $\mathrm{S}_{1}$ & 12.58 & 23.33 & 1.30 & 8.92 \\
\hline $\mathrm{S}_{2}$ & 12.67 & 24.66 & 1.36 & 6.74 \\
\hline $\mathrm{S}_{3}$ & 13.75 & 25.23 & 1.53 & 5.67 \\
\hline $\mathrm{CD}(0.05)$ & 0.797 & 0.979 & 0.936 & 0.502 \\
\hline
\end{tabular}

\section{CONCLUSION}

The study revealed that for high yield and yield attributes the bell pepper plants should be treated with $100 \%$ adhoc recommendation of KAU for precision farming. Among different spacing closer spacing of $45 \mathrm{~cm} \mathrm{x} 30 \mathrm{~cm}$ is ideal for profitable cultivation of plants under polyhouse. Even though interaction of two treatments was not significant, higher net returns ( $₹ 1,88,95610$ cents-1) and B: $\mathrm{C}$ ratio (3.30) were recorded from the plants treated with 100 $\%$ adhoc recommendation of KAU for precision farming along with closer spacing of $45 \mathrm{~cm}$ x $30 \mathrm{~cm}\left(\mathrm{f}_{1} \mathrm{~s}_{1}\right)$.

\section{REFERENCES}

[1] Alam, M. S., Saha, S. R., Salam, M. A., and Alam, M. K. 2011. Effect of sowing time and plant spacing on the yield and yield attributes of bell pepper (Capsicum annuиm L.). Bangladesh J. Agric. Res. 36(1): 271-278.

[2] Aliyu, L. 2002. Growth and yield of pepper (Capsicum annuит L.) as affected by nitrogen and phosphorus application and plant density. Crop Res. Hisar 23(3): 467475.

[3] Biradar, M. S., Patil, A. A., Mantur, S. M., and Mannikeri, I. M. 2014.Influence of growing environment and planting geometry on yield and yield attributes of bell pepper (Capsicum annuum L.var. grossum Sendt.) genotypes.

Karnataka J. Agric. Sci. 27 (2): 202-207.

[4] Hartz, T. K., Legstrange, M., and Mary, D. M. 1993. Nitrogen requirement of drip irrigated pepper. Hortic. Sci. 18(11): 1097-1099.
[5] IIHR [Indian Institute of Horticulture Research]. 2011. Protected Cultivation of Bell pepper. Technical bulletin No.22. IIHR, Bengaluru, 28p.

[6] Joshi, M. C. and D. P. Singh, 1975. Chemical composition in bell pepper. Indian Hortic. 20: 19-21.

[7] Ochigbu, A. A. and Harris, G. P. 1989. Effect of film plastic cover on the growth and yield of bush tomato grown in a bed system. J. Hortic. Sci. 64(1): 300-302.

[8] Shivakumar, S., Hussain, A., Kurubar, A. R., and Patil, M. G. 2012. Yield and yield parameters of bell pepper under different spacingss and fertilizers levels in shade net. Asian J. Hortic. 7(2): 246-249.

[9] Srivastava, A. K. 1996. Effect of fertilizer levels and plant spacings on flowering, fruitset and yield of bell pepper (Capsicum annuum var. grossum L.) cv. Hybrid Bharat. Advan. Plant Sci. 9(2): 171-175.

[10] Zende, U. M. 2008. Investigation on production techniques in bell pepper under protected cultivation. MSc (Ag) thesis, University of Agricultural Sciences, Dharwad, Karnataka, India, 160p. 